\title{
ИНТЕРНЕТ ВЕЩЕЙ на спутниковых технологиях
}

Л.Павлова

DOI: $10.22184 / 2070-8963.2020 .92 .7-8.46 .47$

Онлайн-участники круглого стола "Место спутниковых технологий на рынке Интернета вещей", организованного в рамках "Российской недели высоких технологий - 2020" ФГУП "Космическая связь" (ГП КС) по инициативе Россвязи, обсудили возможности применения и перспективы развития спутниковых технологий в экосистеме ІоТ.

Открывая круглый стол, начальник отдела по развитию и использованию сетей связи Россвязи Роман Антипин зачитал приветственное слово руководителя этого агентства - Олега Духовницкого. "2020 год показал нам, насколько важна связь и насколько она необходима также и там, где существует только спутниковая связь. Поэтому ее развитие и поддержание требует сейчас особенно пристального внимания. Спутниковая связь в настоящее время является основным видом международной и национальной связи на большие и средние расстояния, - отметил в своем приветствии глава ведомства. - В данный момент активно развивается концепция Интернета вещей, что подразумевает внедрение встраиваемых технологий в современные телекоммуникационные сети".

По его словам, в России реализация услуг в сегменте IоT предусматривается в рамках создания многоспутниковой системы "Марафон IоT/ M2M", входящей в подпрограмму "Сфера", которая разработана Госкорпорацией "Роскосмос". Использование спутниковых каналов связи для IоT и сервисов М2М будет расти быстрыми темпами, предоставляя новые возможности для спутниковых операторов по всему миру, а инфраструктура ГП КС потенциально может быть использо вана для реализации системы "Марафон", уверен О.Духовницкий.

Модератором выступил Евгений Буйдинов, заместитель генерального директора по развитию и эксплуатации систем связи ГП КС. В своем докладе о прогнозах развития и роли спутниковой связи в экосистеме ІоТ он отметил, что по оценке ГП КС, к 2030 году на территории России от 100 тыс. до 1 млн устройств будут обслуживаться через спутниковые системы. Е.Буйдинов также рассказал о тестовых проектах предприятия в области IoT. В 2019 году ГП КС совместно с German Orbital Systems успешно провело испытания по передаче коротких сообщений через низколетящий спутник с высотой орбиты 550 км по технологии LoRaWAN. Kaк сообщил Е.Буйдинов, с 2017 года 3АО "ВИСАТ-ТЕЛ" прорабатывает общую архитектуру системы "Марафон IоT" и компонентную базу полезной нагрузки в составе спутниковой группировки. К этой работе подключилось АО "Информационные спутниковые системы" имени академика М.Ф.Решетнева" (ИСС), ряд других компаний. Кроме того, АО "Спутниковая система "Гонец" фактически уже предоставляет услуги в сегменте M2M. Наконец, целый ряд соот ветствующих стартапов курирует Фонд "Сколково".

O международном статусе стандартизации технологии Интернета вещей сделал сообщение Виктор Стрелец, председатель ИК4 MCЭ-R. Он отметил, что уже сегодня немалую часть трафика занимает взаимодействие машин, и парадигма развития IоT - это во многом наше будущее. Стандартизация проводится на международном и национальных уровнях, хотя и не без сложностей. В России 24 августа 2020 года стало известно об утверждении национальных стан дартов для Интернета вещей, Промышленного Интернета вещей и сенсорных сетей. Благодаря утвержденным стандартам проектирование, 
разработка и развитие систем Интернета вещей в России упростятся, отметил В.Стрелец.

В дорожные карты развития сквозных цифровых технологий в России внесены и спутниковые технологии - спутниковые цифровой доступ, Интернет вещей, персональная связь. "Дорожные карты являются в том числе основой для бюджетирования этих проектов, поэтому нужно сказать огромное спасибо в первую очередь специалистам НИИР и лично В.Р.Анпилогову за то, что они приняли очень активное участие в разработке этих дорожных карт и сумели отразить именно спутниковые технологии связи", - подчеркнул В.Стрелец.

С докладом на тему "Многоспутниковая система передачи данных "Марафон IоT": сервисы спутникового Интернета вещей и их конкурентоспособность" выступил заместитель генерального директора ЗАО "ВИСАТ-ТЕЛ" Валентин Анпилогов. ОН представил итоги анализа современных систем и проектов спутникового IоТ, а также рассказал о текущем статусе реализации системы. Основная ее миссия - создание глобально-распределенной сети Интернета вещей на основе спутниковых и наземных каналов. Целевая функция - предоставление сервисов IоT с ценовыми параметрами абонентских устройств и тарифными планами, соизмеримыми с показателями в наземных сетях. Предполагается, что система будет состоять из 264 спутников массой 45-50 кг на полярных орбитах, с прямым доступом к датчиками и сбором информации с них. Работа от абонентского устройства должна осуществляться от батарейки 5-10 лет.

В "Марафоне" предполагается использовать практически те же устройства, что и в сетях LoRa отличается только антенна. "Есть все основания говорить, что в системе будут достигнуты ценовые и эксплуатационные параметры, соизмеримые с наземными сетями", - уверен Р.Анпилогов. Кстати, в октябре 2020 года ПАО "МТС" вошло в инициативную рабочую группу "Роскосмоса" по разработке системы "Марафон".

Опережающий аванпроект системы "Марафон IоT" представил Александр Кузовников, заместитель генерального конструктора по разработке космических систем, общему проектированию и управлению космическими аппаратами (КА) ИСС. В настоящий момент в ИСС ведется разработка аванпроекта группировки, в следующем году планируется разработка эскизного проекта. Изготовление и запуск шести спутников-демонстраторов планируется во втором квартале
2023 года, развитие системы "Марафон IоT" для глобального обслуживания - на 2025-2028 годы.

А.Кузовников сообщил, что для развертывания группировки "Марафон ІоТ" из 264 КА потребуется три года. При этом половину спутников для обслуживания регионов, расположенных выше $50^{\circ}$ с. ш., планируется запустить в третьем квартале 2024 года, тогда же ввести в эксплуатацию наземный сегмент. Изготовление опытного образца КА "Марафон" намечено на второй квартал 2022 года; создание технического комплекса космических аппаратов - на первый квартал 2023 года; изготовление и запуск шести КА-демонстраторов - на второй квартал 2023 года; проведение летных испытаний, формирование наземного комплекса управления и центра сопряжения системы связи - на четвертый квартал 2024 года; изготовление и запуск космических аппаратов для формирования полной орбитальной группировки для обслуживания регионов выше $50^{\circ}$ с. ш. - на четвертый квартал 2025 года. Стоимость серийного спутника на заводе-изготовителе составит не более 35 млн руб. Срок активного существования спутников составит четырепять лет с возможностью увеличения до семи.

ИСС планирует отправить для испытаний на Международную космическую станцию оборудование, разработанное для группировки "Марафон", поскольку пока не до конца понятна эффективность работы протокола LoRaWAN на разных типах орбит из-за возникновения эффекта Доплера, смещения частот. Конечные устройства LoRaWAN, говорится в презентации представителя ИСС, обеспечивают опрос типовых датчиков, в том числе температуры, давления, влажности и пр.

С сообщением о месте спутниковой системы "Гонец" на рынке ІоТ выступил Максим Диордиев, руководитель дирекции по применению спутниковых систем АО "Спутниковая система "Гонец". О российских стартапах в области IоТ рассказал Иван Косенков, старший проектный менеджер кластера передовых производственных технологий, ядерных и космических технологий Фонда "Сколково". В дискуссиях круглого стола также приняли участие генеральный директор ООО "ЭС-ПАС" Александр Сальман, акционер АО "Ка-Интернет" Сергей Пехтерев, заместитель директора НТЦ космических систем ФГУП НИИР Олег Ментус и представители операторов-Алексей Дьяченко, ведущий эксперт по развитию спутниковой сети "МегаФон", и Владимир Валькович, директор по стратегии и долгосрочному планированию развития сети "ВымпелКом". 